УДК 553.98.042:622.32 (571.12)

\title{
РАЗВИТИЕ НЕФТЕГАЗОВОГО КОМПЛЕКСА ЮГРЫ, ТРУДНОИЗВЛЕКАЕМЫЕ ЗАПАСЫ
}

Кузьменков Станислав Григорьевич',

ksg.1948@ya.ru

Исаев Валерий Иванович ${ }^{21}$, isaevvi@tpu.ru

Булатов Валерий Иванович', bulatov.40@mail.ru

Аюпов Роман Шамильевич', ayupovrsh@gmail.com

Игенбаева Наталья Олеговна', nataligeo@yandex.ru

Кузьмин Юрий Алексеевичз, kuzmin@crru.ru

Стулов Пётр Александрович 4 , StulovPA@nacrn.hmao.ru

1 Югорский государственный университет, Россия, 628012, г. Ханты- Мансийск, ул. Чехова, 16.

2 Национальный исследовательский Томский политехнический университет, Россия, 635050, г. Томск, пр. Ленина, 30.

${ }^{3}$ АУ «Научно-аналитический центр рационального недропользования им. В.И. Шпильмана», Россия, 625026, г. Тюмень, ул. Малыгина, 75.

${ }^{4}$ АУ «Научно-аналитический центр рационального недропользования им. В.И. Шпильмана», Россия, 628007, г. Ханты-Мансийск, ул. Студенческая, 2.

Актуальность. Ключевой задачей для Ханты-Мансийского автономного округа-Югры - основной базы углеводородного сырья и нефтедобычи России - является предотвращение снижения, стабилизация добычи нефти. Этого можно достичь за счёт активного вовлечения в разработку трудноизвлекаемых запасов нефти.

Цель исследования: определить источники, направления и приоритеты наращивания ресурсной базы нефти и стабилизации добычи в Югре, акцентируя потенциал трудноизвлекаемых запасов.

Обьект: запасы и ресурсы по распределенному и нераспределенному фондам недр, объемы добычи нефти по основным нефтяным компаниям и крупным месторождениям, нефтегазоносным комплексам.

Методы: ретроспективный анализ и прогнозирование динамики запасов и добычи нефти, нефтегеологическая и горногеологическая классификация трудноизвлекаемых запасов.

Результаты. Анализировались данные Департамента по недропользованию ХМАО-Югры и Научно-аналитического центра рационального недропользования им. В.И. Шпильмана. 98,9 \% добычи нефти в Югре принадлежит девяти интегрированным нефтяным компаниям, 51,7 \% добычи нефти приходится на 14 крупных месторождений. Целенаправленно анализируется состояние добычи нефти в Югре с 1964 г., с детализацией начиная с 2008 г., когда был подготовлен прогноз снижения добычи на период до 2030 г. По состоянию на 2018 г. прогноз полностью подтвердился. Названы закономерные причины снижения добычи, с прогнозом снижения до 220 млн т к 2020 г. Среди причин - открываемые и вводимые в разработку в последние годы объекты, как правило, являются с преимущественно трудноизвлекаемыми запасами. С учетом геологических и горногеологических факторов выделены семь групп залежей с трудноизвлекаемыми запасами и дана фактическая дифференциация залежей нефти Югры. Показано, что одним из реальных источников, обеспечивающих стабилизацию добычи, является активное вовлечение в разработку залежей с трудноизвлекаемых запасов ачимовского и тюменского комплексов, по которым с 2000 г. добыча увеличилась в 5-10 раз. Возможен рост добычи трудноизвлекаемых запасов доюрского комплекса, накопленная добыча которого составляет 32 млн т. Ресурсы баженовского-абалакского комплекса, которые до 2030 г. будут вовлечены в разработку, могут восполнить падающую добычу нефти в Югре.

\section{Ключевые слова:}

Снижение нефтедобычи, трудноизвлекаемые запасы, баженовско-абалакский комплекс, ачимовский, тюменский и доюрский комплексы, Югра. 


\section{Введение}

Для поддержания уровня добычи углеводородного сырья (УВС) в России нужны новые, соизмеримые по ресурсам с Западно-Сибирской, базы нефтедобычи, опирающиеся на уникальные и крупные месторождения, которые обычно выявляются в начальной стадии освоения нефтегазоносных провинций. Такие базы нефтедобычи ещё нужно создать за счёт проведения масштабных геологоразведочных работ, финансируемых государством $[1,2]$.

Ни в Восточной Сибири, ни на шельфах не накоплена критическая масса доказанных запасов, необходимая для разворота масштабных работ. В табл. 1 представлены данные (ВНИГНИ, 2014) по ресурсам нефти - начальным суммарным (HCP) и в сумме по прогнозным и перспективным (Д+- $\left.\mathrm{C}_{3}\right)$.

Порядок цифр по невыявленным ресурсам $\left(Д_{2}\right)$ сопоставим по всем территориям (исключая Дальневосточный шельф). Но по Ханты-Мансийскому автономному округу-Югре (Югре) ресурсов Д (в районах с неустановленной нефтеносностью) всего 1,5 из 13,2 млрд т, а в Арктических акваториях 9,1 из 12,5 млрд т. В Югре сосредоточена почти половина (44 \%) прогнозных ресурсов категории Д Р Российской Федерации, т. е. ресурсов в отложениях и на территориях с доказанной нефтеносностью. В акваториях - пока только недоказанные перспективы.

В Восточной Сибири есть несколько крупных месторождений, открытых ещё в советские годы, но новых серьёзных открытий пока нет. ВСТО в значительной мере должен рассчитывать на запасы Западной Сибири [3]. Поэтому Югра ещё долгие годы будет оставаться основной базой нефтедобычи России.
Таблица 1. Начальные суммарные ресурсы УВС и в сумме по

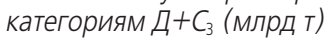

Table 1. Total initial resources of hydrocarbon crude (HC) by categories $D+C_{3}$ (billion tons)

\begin{tabular}{|c|c|c|}
\hline $\begin{array}{l}\text { Территория } \\
\text { Area }\end{array}$ & $\begin{array}{c}\text { HCP } \\
\text { Total initial resources }\end{array}$ & $\mathrm{Z}+\mathrm{C}_{3}$ \\
\hline $\begin{array}{l}\text { XМАО-Югра } \\
\text { Khanty-Mansiysk Autonomous } \\
\text { District-Yugra }\end{array}$ & 35,5 & 13,2 \\
\hline $\begin{array}{l}\text { Восточная Сибирь (Красноярский } \\
\text { край, Иркутская обл., Якутия) } \\
\text { Eastern Siberia (Krasnoyarsk } \\
\text { Territory, Irkutsk Region, Yakutia) }\end{array}$ & 14,6 & 11,3 \\
\hline $\begin{array}{l}\text { ЯНAO } \\
\text { Yamalo-Nenets Autonomous District }\end{array}$ & 14,7 & 8,8 \\
\hline $\begin{array}{l}\text { Арктические акватории } \\
\text { Arctic water areas }\end{array}$ & 13,0 & 12,5 \\
\hline $\begin{array}{l}\text { Дальневосточные акватории Far } \\
\text { East water areas }\end{array}$ & 2,3 & 1,8 \\
\hline
\end{tabular}

Ключевой задачей для нефтедобывающей отрасли Югры является предотвращение снижения добычи нефти [4]. Этого можно достичь за счёт расширения географии геологоразведочных работ с целью подготовки «новых» запасов нефти, повышения и доведения коэффициента извлечения нефти (КИН) как минимум до среднероссийского уровня, и активного вовлечения в разработку трудноизвлекаемых запасов нефти (ТрИЗ).

\section{Состояние добычи нефти в Югре}

Объем добычи нефти в целом по России в 2017 г. составил 546,7 млн т, что на $0,1 \%$ меньше добычи в 2016 г. На долю Югры приходится 43,0 \% общероссийской добычи, в то время как по итогам 2016 г. этот показатель составлял 43,7 \% (рис. 1).

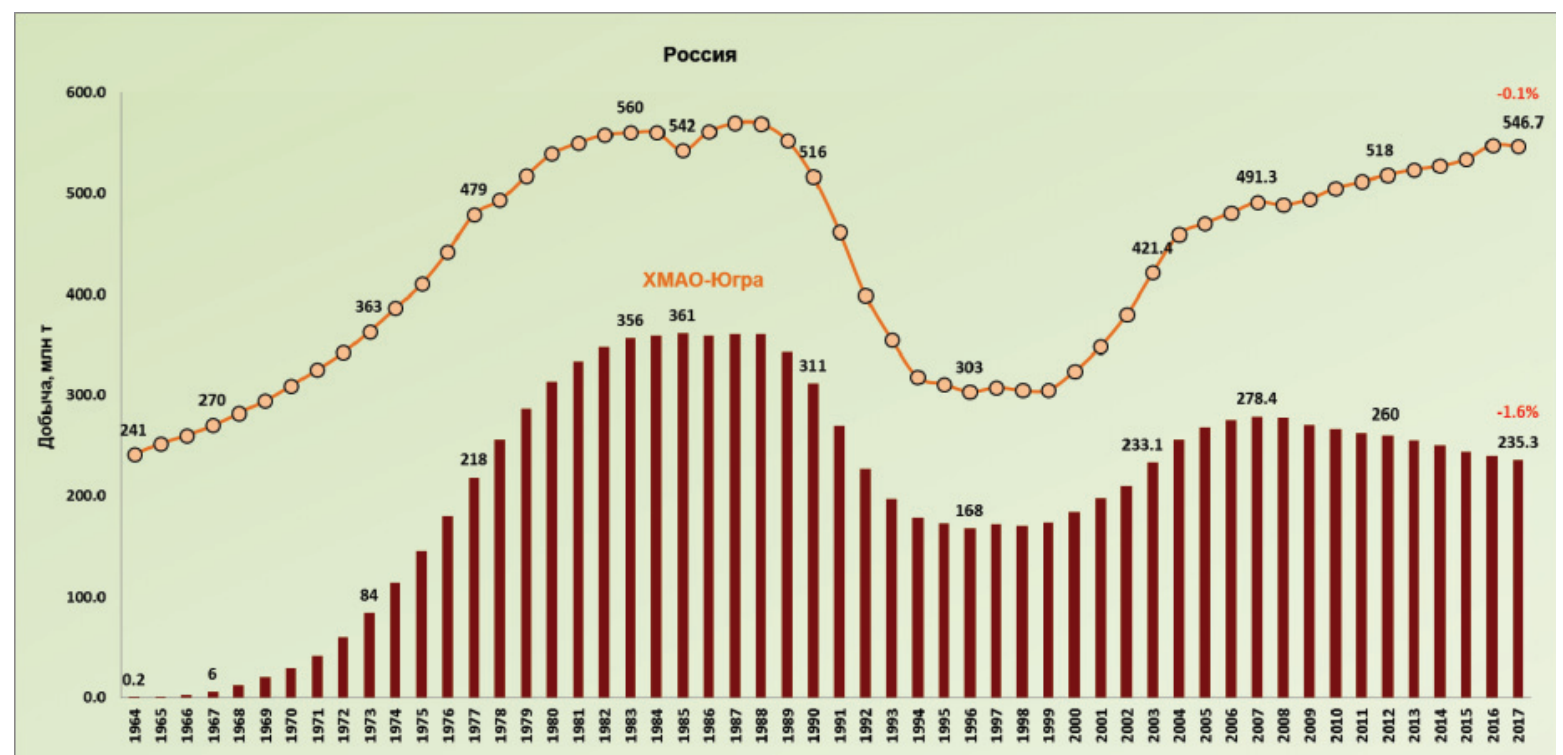

Pис. 1. Динамика годовой добычи нефти в ХМАО-Югре с начала разработки (по данным Департамента по недропользованию ХМАО-Югры, 2018 г.)

Fig. 1. Trend of annual oil production in the Khanty-Mansiysk Autonomous District (Yugra) from the beginning of development work (according to the Department of Subsoil Use of Yugra, 2018) 


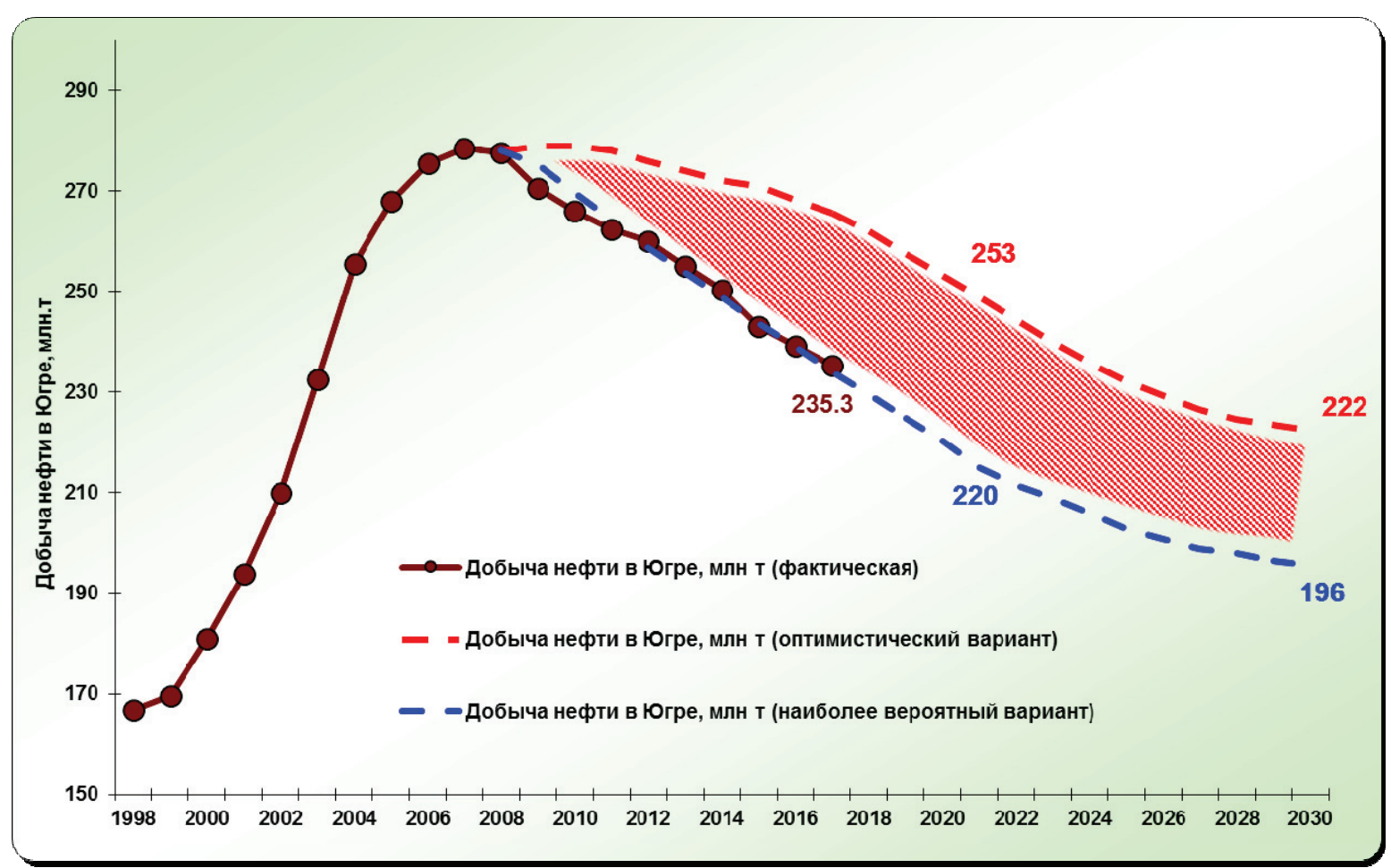

Рис. 2. Прогноз и фактическая годовая добычи нефти в ХМАО-Югре (по данным НАЦ РН им. В.И. Шпильмана)

Fig. 2. Predicted and practical annual oil production in the Khanty-Mansiysk Autonomous District (according to Research and Analytical Center for Rational Use of the Subsoil named after V.I. Shpilman)

С 1964 г., с начала разработки нефтяных месторождений на территории Ханты-Мансийского автономного округа, накопленная добыча нефти составила на 1 января 2018 г. 11443 ллн m. Основной объект разработки- шельфовые песчаники неокома.

Всего, по данным Департамента по недропользованию ХМА0-Югры, по состоянию на 01.01.2018 г. на территории автономного округа открыто 483 лесторождения нефти и газа, 257 из них находятся в разработке. В распределенном фонде недр (РФН) на различных стадиях изученности числится 123 месторождения с извлекаемыми запасами более 1,0 млрд т, в нераспределенном фонде недр (НФН) на государственный баланс поставлено 91 месторождение с извлекаемыми запасами более 0,3 млрд т.

В 2017 г. на территории автономного округа добыча нефти составила 235,3 млн т нефти, что на 1,6 \% меньше добычи в 2016 г. или в абсолютных единицах - на 3,9 млн т. Отметим, что в 2016-2017 гг. наметилась тенденция к сокращению снижения добычи нефти относительно предшествующего отчетного периода, что можно объяснить как внедрением новых технологий повышения нефтеотдачи и интенсификации притока, так и активным вводом «новых» месторождений.

По состоянию на 01.06.2018 г. деятельность, связанную с геологическим изучением недр и добычей УВС, на территории Югры осуществляют
110 предприятий-недропользователей. 36 предприятий входят в состав 7 вертикально интегрированных компаний, 74 общества являются независимыми. От общей добычи нефти по ХMAO 98,9% принадлежит 9 крупным нефтяным компаниям (ПАО «НК «Роснефть», ОАО «Сургутнефтегаз», ПАО «ЛУКОЙЛ», ОАО НГК «Славнефть», ПАО «Газпром нефть», «Салым Петролеум Девелопмент Н.В.», ПАО НК «РуссНефть», ОАО «Томскнефть» ВНК, ПАО АНК «Башнефть) и лишь 1,1 \% добывают 14 независимых производителей.

При этом в 2017 г. 51,7 \% добычи нефти приходится на 14 крупных месторождений, на каждом из которых добыто более 3 млн т. Наибольший объём добычи нефти приходится на Приобское месторождение - более 36 млн т (ПАО «НК «Роснефть» + ПАО «Газпром нефть»), Самотлорское - почти 19 млн т (ПАО «НК «Роснефть»), Приразломное $-9,2$ млн т (ПАО «НК «Роснефть») и Фёдоровское - 8,5 млн т (ОАО «Сургутнефтегаз»).

В 2008 г., при подготовке предложений для формирования энергетической стратегии до 2020 г. и на перспективу, экспертами АУ «Научно-аналитический центр рационального недропользования им. В.И. Шпильмана» (НАЦ РН им. В.И. Шпильмана) был подготовлен прогноз снижения добычи нефти на территории ХMAO-Югры на период до 2030 г. (рис. 2). Как следует из представленного графика, по состоянию на 2018 г. прогноз (наиболее вероятный вариант) полностью подтвердился. 
Как видим, снижение добычи нефти на территории автономного округа прогнозируемое и закономерное. Основные причины снижения добычи нефти:

1) значительная часть месторождений находится на поздних стадиях разработки, которые характеризуются естественным снижением объема добычи нефти в связи с истощением запасов и обводнением продукции;

2) эксплуатационное бурение перемещается в краевые зоны месторождений, где его эффективность существенно ниже, а вовлекаемые в разработку запасы не в состоянии компенсировать сокращение добычи вследствие выработки высокопродуктивных зон;

3) заметно снижаются объемы добычи нефти на крупнейших месторождениях, которые вносят значительный вклад в общую добычу по округу (Самотлорское, Федоровское, Западно-Салымское, Тевлинско-Русскинское, Ватьеганское, Мамонтовское)

4) на протяжении последних лет продолжает ухудшаться структура разведанных запасов, в округе открываются всё более мелкие, малодебитные месторождения и залежи, открытие новых крупных нефтяных месторождений маловероятно;

5) открываемые и вводимые в разработку в последние годы объекты, как правило, являются низкопродуктивными, с незначительными, преимущественно с трудноизвлекаелыми запасами нефти, характеризуются более сложным геологическим строением, что делает такие объекты малопривлекательными для инвестиций.

Если темпы снижения добычи нефти в Югре останутся в соответствии с прогнозом (рис. 2), то к 2020 г. добыча в округе составит 220 млн т, а к 2030 г. снизится до 196 млн т. Что необходимо предпринять для стабилизации добычи нефти в Югре? Ответ, на наш взгляд, есть. Предотвращение снижения добычи нефти нефтедобывающей отрасли Югры можно достичь за счёт:

1) расширения географии геологоразведочных работ с целью подготовки «новых» запасов нефти;

2) подготовки в ближайшее время и вовлечения в промышленную разработку 214 месторождений РФН и НФН с запасами около 1,5 млрд т $\mathrm{YBC}$;

3) повышения и доведения коэффициента извлечения нефти (КИН) как минимум до среднероссийского уровня;

4) активного вовлечения в разработку трудноиз влекаелых запасов нефти.

Остановимся более подробно на последнем направлении.

\section{Трудноизвлекаемые запасы нефти Югры}

Причины трудноизвлекаемости запасов нефти, в соответствии с «Классификацией трудноизвлекаемых запасов (ТрИЗ)» [5], можно разделить на две составляющие: естественные и техногенные, в соответствии с которыми при определении принадлежности залежей к группе ТрИЗ необходимо использовать геологические, технологические и экономические критерии.

В «Классификации...» достаточно формализованы геологические критерии трудноизвлекаемости по свойствам нефтей, к которым можно отнести вязкость (>30 мПа.c), битуминозность (плотность при $20{ }^{\circ} \mathrm{C}>0,895 \mathrm{r} / \mathrm{cm}^{3}$ ) нефти, содержание в ней парафина $(>6 \%)$ и серы $(>3,5 \%)$. Эти параметры и их граничные значения учитывают технологию добычи, транспортировки, переработки сырья, обеспечивают его комплексное использование и содержатся в характеристиках залежей данных Госбаланса РФ.

По данным Государственного баланса запасов в достаточной степени достоверно судить о доле и характеристике ТрИЗ можно, используя только названные выше геологические критерии их определения. По остальным геологическим критериям в данных Госбаланса формализованные признаки отсутствуют за исключением проницаемости, значением которой охарактеризовано лишь менее половины залежей. Тем не менее при дифференциации данных Госбаланса учитывались граничные параметры, принятые ЦКР Роснедра [6], в части фильтрационно-емкостных свойств коллекторов (пористость, нефтенасыщенность), наличия двойной пористости, прерывистости и расчленённости пластов и характеристики контактов «нефть-пластовая вода» или «нефть-газовая шапка».

По признакам аномальности свойств нефтей и газов, неблагоприятности характеристик коллекторов, типам контактных зон, технологическим причинам (выработанность) и горногеологическим факторам на месторождениях XMA0-Югры выделены залежи с трудноизвлекаемыми запасами нефти, объединенные в следующие семь групп.

1. Залежи нефти с анолальными физико-хилическили свойствали: залежи высоковязкой (>30 мПа.с), битуминозной (плотность при $\left.20{ }^{\circ} \mathrm{C}>0,895 \mathrm{r} / \mathrm{cm}^{3}\right)$, высокопарафинистой $(>6 \%)$ и особо высокосернистой $(>3,5 \%)$ нефти.

2. Отложения пласта $A B_{1}{ }^{1-2}$ типа «рябчик»: резкая литологическая неоднородность латеральная и вертикальная, тонкое переслаивание песчаных и глинистых включений различной формы и размеров, преобладание коллекторов «рябчикового» типа, КИН $<0,230$.

3. Породы доюрского колплекса (ДЮК): принадлежность залежей к комплексу пород фундамента и образованиям пермо-триасового возраста. Латеральная и вертикальная неоднородность фильтрационно-емкостных свойств (ФЕС) резервуара, преобладающий тип коллектора - кавернозно-порово-трещинный, КИН $<0,230$.

4. Тюленская свита: мозаичное строение толщи с высокой степенью неоднородности разреза (различного размера и формы линзы коллекто- 
ров в толще глинистых пород), наличие множества «рукавообразных» изолированных песчаных тел, высокая степень послойной и зональной фильтрационной неоднородности отложений, КИН $<0,230$.

5. Ачиловская толща: залежи нефти приурочены к очень сложным ловушкам клиноформного строения с неравномерным, часто линзовидным переслаиванием алевролитов, песчаников и аргиллитоподобных глин. Неоднородный характер строения резервуара как по латерали, так и по разрезу, преимущественно невысокие фильтрационно-емкостные свойства коллекторов, КИН $<0,230$.

6. Подгазовые зоны залежей: нефтегазоконденсатные залежи с нефтяными оторочками небольшой мощности (около $4 \mathrm{~m}$ ), КИН $<0,230$.

7. Баженовская свита: принадлежность к отложениям баженовской свиты. Сложное геологическое строение залежей с резкой латеральной и вертикальной неоднородностью резервуара, коллекторы вторичного генезиса трёх типов: порово-трещинного, трещинного и трещиннокавернозного с низкими фильтрационно-емкостными свойствами.

Дополнительно при отнесении залежей очень сложного геологического строения к группе ТрИЗ использована предельная величина КИН, равная, по экспертной оценке, 0,230 [7].

В табл. 2 представлена фактическая дифференциация залежей ТрИЗ Югры по геологическим параметрам.

Согласно последней официальной экспертной оценке, начальные суммарные геологические ресурсы отложений баженовско-абалакского нефтегазоносного комплекса (НГК) в Югре оцениваются в 11 млрд т, извлекаемые ресурсы нефти оценены в 3,1 млрд т, извлекаемые запасы категорий $\mathrm{C} 1+\mathrm{C} 2$ оценены в 500 млн т. Вместе с тем за 50 лет промышленной разработки из отложений баженовской свиты добыто чуть более $11 \mathrm{млн} \mathrm{тонн} \mathrm{неф-}$ ти, что составляет доли процента от поставленных на Госбаланс ресурсов по этому комплексу. В 2017 г., по данным Департамента по недропользованию Югры (рис. 3), из отложений баженовской свиты было добыто 536 тыс т - это свидетельствует о том, что эффективное освоение трудноизвлекаемых запасов нефти баженовских отложений возможно лишь при условии проведения активной государственной политики, включая внедрение организационных и технологических инноваций.

C ресурсами баженовской свиты, которые до 30-х гг. текущего столетия могут быть вовлечены в разработку и восполнить падающую добычу из месторождений в Югре, находящихся в поздней стадии разработки, геологи связывают большие надежды [8-12].

С 1967 г., после подтверждения наличия нефти в баженовской свите Правдинского месторождения, залежи нефти в битуминозных аргиллитах открыты в других нефтеносных районах Западной
Сибири, площадь их распространения составляет от 700 тыс. до 1 млн км² [13]. Введение в активную разработку трудноизвлекаемых запасов сложнопостроенных залежей баженовских отложений на сегодняшний день представляет собой важную отраслевую задачу [14-18].

Табл. 2. Характеристики фактического отнесения залежей нефти к ТрИЗ (по данным НАЦ РН им. В.И. Шпильмана, 2014)

Table 2. Internals of practical referring oil deposits to the hard to recover (HTR) reserves (according to Research and Analytical Center for Rational Use of the Subsoil named after V.I. Shpilman, 2014)

\begin{tabular}{|c|c|c|c|c|c|c|}
\hline $\begin{array}{c}\text { Параметры ТрИЗ } \\
\text { HTR reserves cha- } \\
\text { racteristic }\end{array}$ & 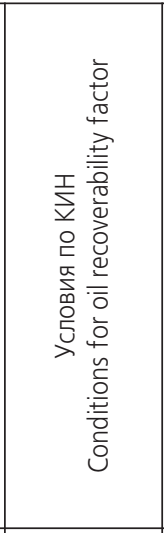 & 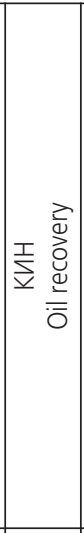 & 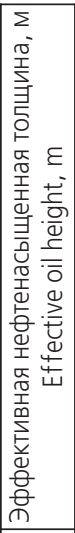 & 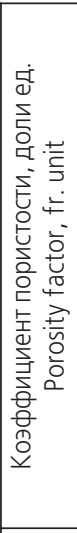 & 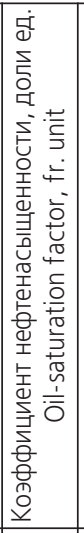 & 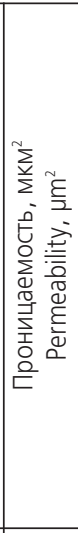 \\
\hline $\begin{array}{l}\text { Свойства нефти } \\
\text { (вязкость, } \\
\text { плотность, } \\
\text { содержание } \\
\text { парафина и серы) } \\
\text { Oil properties } \\
\text { (viscosity, gravity, } \\
\text { paraffin and } \\
\text { sulphur content) }\end{array}$ & $\begin{array}{c}\text { ТрИЗ } \\
\text { HTR reserves }\end{array}$ & 0,258 & 3,6 & 0,203 & 0,59 & 0,190 \\
\hline \multirow{2}{*}{$\begin{array}{l}\text { «Рябчик» } \\
\text { «Ryabchik» }\end{array}$} & $\begin{array}{l}\text { Bce } \\
\text { All }\end{array}$ & 0,319 & 5,2 & 0,218 & 0,441 & 0,215 \\
\hline & \begin{tabular}{c|} 
ТрИЗ \\
HTR reserves
\end{tabular} & 0,211 & 3,1 & 0,202 & 0,425 & 0,054 \\
\hline \multirow{2}{*}{$\begin{array}{l}\text { ДЮК } \\
\text { Pre-Jurassic play }\end{array}$} & \begin{tabular}{|l|} 
Bce \\
All \\
\end{tabular} & 0,205 & 10,1 & 0,133 & 0,628 & 0,170 \\
\hline & $\begin{array}{c}\text { ТрИЗ } \\
\text { HTR reserves } \\
\end{array}$ & 0,194 & 10,1 & 0,139 & 0,604 & 0,182 \\
\hline \multirow{2}{*}{$\begin{array}{l}\text { Тюменская свита } \\
\text { Tyumen formation }\end{array}$} & \begin{tabular}{|l|} 
Bce \\
All \\
\end{tabular} & 0,231 & 3,9 & 0,156 & 0,552 & 0,022 \\
\hline & \begin{tabular}{c|} 
ТрИЗ \\
HTR reserves \\
\end{tabular} & 0,209 & 3,1 & 0,153 & 0,546 & 0,014 \\
\hline \multirow{2}{*}{$\begin{array}{l}\text { Ачимовские } \\
\text { отложения } \\
\text { Achimov deposits }\end{array}$} & $\begin{array}{c}\text { Bce } \\
\text { All }\end{array}$ & 0,258 & 3,5 & 0,176 & 0,511 & 0,700 \\
\hline & \begin{tabular}{c|} 
ТрИЗ \\
HTR reserves \\
\end{tabular} & 0,199 & 3,4 & 0,173 & 0,506 & 0,065 \\
\hline \multirow{2}{*}{$\begin{array}{l}\text { Подгазовые } \\
\text { залежи } \\
\text { Below the gas cap } \\
\text { deposits }\end{array}$} & $\begin{array}{l}\text { Bce } \\
\text { All } \\
\end{array}$ & 0,373 & 4,3 & 0,233 & 0,553 & 0,192 \\
\hline & \begin{tabular}{c|} 
ТрИЗ \\
HTR reserves \\
\end{tabular} & 0,221 & 3,5 & 0,237 & 0,509 & 0,169 \\
\hline $\begin{array}{l}\text { Баженовская свита } \\
\text { Bazhenov } \\
\text { formation }\end{array}$ & $\begin{array}{c}\text { ТрИз } \\
\text { HTR reserves }\end{array}$ & 0,245 & 3,4 & 0,173 & 0,506 & 0,065 \\
\hline
\end{tabular}

Баженовская свита - это не единственный перспективный объект ТрИЗ в разрезе осадочного чехла Западно-Сибирской нефтегазоносной провин- 


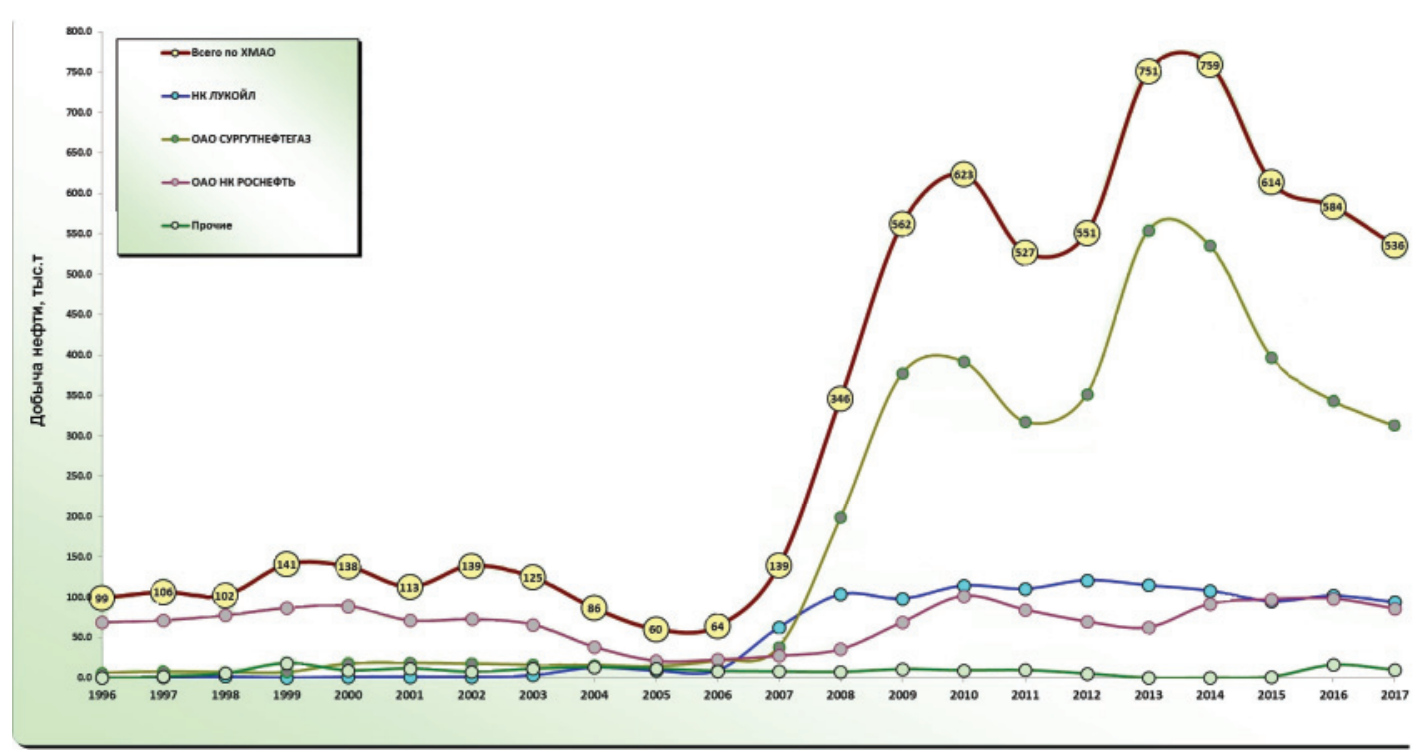

Рис. 3. Динамика годовой добычи нефти из отложений баженовско-абалакского НГК в Ханты-Мансийском автономном округе

Fig. 3. Trend of annual oil production from deposits of Bazhenov-Abalak play in the Khanty-Mansiysk Autonomous District

ции. Многомиллиардным потенциалом обладают отложения ачимовской части осложненного неокомского комплекса, извлекаемые запасы по которому составляют более 2 млрд т, и тюменской свиты, в которой только к залежам с ТрИЗ относятся более 5 млрд т. Коллектор тюменской свиты имеет в основном континентальный генезис [19], что приводит к ухудшению фильтрационно-емкостных свойств по сравнению с шельфовыми песчаниками неокома (основным объектом разработки в автономном округе) и, в конечном итоге, к низким дебитам добывающих скважин.

Добыча нефти из залежей ачимовского комплекса [20], отнесенного к ТрИЗ, с 2000 г. увеличилась в пять раз и составила 21 млн т в 2017 г., а из отложений тюменской свиты (с ТрИЗ) добыча с 2,6 млн т в 2000 г. выросла до $26 \mathrm{млн} \mathrm{т,}$ т. е. практически в 10 раз.

К отложениям пластов с «рябчиковой» текстурой, отнесенных к ТрИЗ, приурочено более 10 залежей с начальными геологическими запасами нефти всех категорий около 0,2 млрд т, основная часть которых сосредоточена на месторождениях Большого Самотлора. По состоянию на 01.06.2018 г. накопленная добыча нефти из пластов этой группы ТрИЗ составила чуть более 1,5 млн т.

K образованиям доюрского комплекса (ДЮК) приурочено около 50 залежей месторождений Югры, расположенных в западной части округа, с начальными геологическими запасами нефти всех категорий около 0,5 млрд т. Основная часть запасов сосредоточена в отложениях триаса и коры выветривания. Достоверность оценки параметров и запасов невысока в силу сложного литолого-минералогического состава пород и типа коллекторов.

Однако суммарно, за всю историю промышленной эксплуатации месторождений, из указанных выше залежей с ТрИЗ добыча нефти в Югре составила около 3 \% от начальных извлекаемых запасов по ним и сотые доли процента от общей добычи нефти по автономного округу.

Вместе с тем отметим, что одним из реальных источников, обеспечивающих стабилизацию добычи нефти в Югре, стало активное вовлечение в разработку залежей с ТрИЗ. Только по трём комплексам (ачимовский, баженовско-абалакский и тюменский) с ТрИЗ прирост добычи нефти в 2017 г. относительно предыдущего периода составил почти 4 млн т, что выше или сопоставимо с темпами снижения добычи в целом по округу.

По ДЮК роста добычи нефти добиться пока не удается. Тем не менее годовая добыча составляет 2-3 млн т, а накопленная добыча из залежей ДЮК за всю историю разработки составила более 32 млн т. Не исключено [21-25], что и ДЮК может быть одним из источников стабилизации добычи нефти в Югре.

\section{Заключение}

Подводя итоги о состоянии дел в нефтегазовом комплексе Югры, можно констатировать следующее.

1. Югра была, есть и будет ещё долгие годы основной базой нефтедобычи России.

2. Пути наращивания ресурсной базы нефти и стабилизация добычи в XМА0-Югре связаны с опоискованием перспективных малоизученных районов (поисковых зон), в пределах которых следует ожидать открытия новых месторождений.

3. Вовлечение в разработку залежей с ТрИЗ показало, что темпы снижения добычи нефти в автономном округе можно не только стабилизировать, но и остановить. 
4. Необходимо активное вовлечение в промышленную разработку и освоение ТрИЗ, в т. ч. залежей ачимовской, баженовской, абалакской, тюменской свит, нефтей ДЮК.

5. Актуально создание и функционирование опытных научно-производственных полигонов, в первую очередь, для внедрения технологий поиска, разведки, исследований, подсчета запасов залежей баженовско-абалакского нефтегазоносного комплекса.

Россия обладает самым значительным резервом трудноизвлекаемых запасов. По оценке ученых и экспертов-геологов международных

\section{СПИСОК ЛИТЕРАУРЬ}

1. Kontorovich A.E. I.M. Gubkin's paradigm of the development of the USSR oil industry in the 20th century / / Russian Geology and Geophysics. - 2017. - V. 58. - № 3-4. - P. 283-293.

2. Kontorovich A.E., Eder L.V., Filimonova I.V. Paradigm oil and gas complex of Russia at the present stage // IOP Conference Series: Earth and Environmental Science. - 2017. - № 88 - P. 1-5. URL: http://iopscience.iop.org/article/10.1088/1755-1315/ 84/1/012010/pdf (дата обращения 10.08.2018).

3. Kontorovich A.E., Eder L.V., Filimonova I.V. Key Problems in the Development of the Power of Siberia Project // Regional Research of Russia. - 2018. - V. 8. - № 1. - P. 92-100.

4. Шпильман А.В. Тенденции развития нефтегазовой отрасли и возможности стабилизации добычи нефти в Югре // Пути реализации нефтегазового и рудного потенциала Ханты-Мансийского автономного округа-Югры. Т. 1. - Ханты-Мансийск: ИздатНаукаСервис, 2012. - С. 29-36.

5. Лисовский Н.Н., Халимов Э.М. 0 классификации трудноизвлекаемых запасов // Вестник ЦКР Роснедра. - 2005. - № 1. C. $33-35$.

6. Классификация запасов нефти и горючих газов. - М.: МПР РФ, 2013. - 9 c

7. Стабилизация добычи нефти в Югре за счёт трудноизвлекаемых запасов - миф или реальность / С.М. Полукеев, А.В. Шпильман, Ю.А. Кузьмин, С.Г. Кузьменков, В.В. Коркунов, М.В. Новиков // Недропользование XXI век. - 2013. № 5. - C. 12-19.

8. Кузьменков С.Г. В Югре создаётся полигон «Баженовский» // Недропользование XXI век. - 2014. - № 5. - С. 9-11.

9. Searches Shale Oil in Western Siberia / G.A. Lobova, V.I. Isaev, A.N. Fomin, V.V. Stotsky // International Multidisciplinary Scientific Geoconference (SGEM 2016): Science and Technologies in Geology, Exploration and Mining: Conference Proceedings. - Albena, 28 June - 7 July 2016. - Sofia: STEF92 Technology Ltd, 2016. - V. 1-3. - P. 941-948.

10. Зубков М.Ю. Региональный прогноз нефтеносности баженовской свиты // Геология и геофизика. - 2017. - Т. 58. № 3-4. - C. 504-510.

11. Belozerov V.B., Krasnoshchekova L.A., Merkulov V.P. Shale strata development problems and origin of the Bazhenov Formation fractures in the southeast of the West Siberian Plate // Russian Geology and Geophysics. - 2018. - V. 59. - № 1. - P. 88-95.

12. Критерии нефтеносности отложений баженовской свиты М.Б. Скворцов, В.Д. Немова, И.В. Панченко, А.М. Кирсанов // Геология нефти и газа. - 2018. - № 1. - С. 109-114.

13. The Bazhenov Horizon of West Siberia: structure, correlation, and thickness / S.V. Ryzhkova, L.M. Burshtein, S.V. Ershov, V.A. Kazanenkov, A.E. Kontorovich, V.A. Kontorovich, A.Y. Nekhaev, B.L. Nikitenko, M.A. Fomin, B.N. Shurygin, агентств, извлекаемые запасы ТрИЗ составляют 20 млрд т, ресурсы - 140 млрд т. Введение в активную разработку ТрИЗ сложно построенных залежей баженовско-абалакского НГК на сегодняшний день представляет собой важнейшую задачу для всей нефтедобывающей отрасли.

Авторы благодарят директора Департамента недропользования и природных ресурсов ХМАО-Югры Сергея Александровича Филатова и директора $А У$ «Научно-аналитический центр рационального недропользования ил. В.И Шпильмана» Александра Владимировича Шпильмана за предоставленную возможность использовать геологическую информацию.

A.L. Beizel, E.V. Borisov, O.V. Zolotova, L.M. Kalinina, E.V. Ponomareva // Russian Geology and Geophysics. 2018. - V. 59. № 7. - P. 846-863.

14. Прищепа 0.М., Аверьянова 0.Ю. К обсуждению понятийной базы нетрадиционных источников нефти и газа - сланцевых толщ // Нефтегазовая геология. Теория и практика. - 2013. Т. 8. - № 3. URL: http://www.ngtp.ru/rub/9/27_2013.pdf (дата обращения 10.08.2018).

15. Трудноизвлекаемые запасы нефти баженовских отложений ХМА0-Югры / Ю.А. Кузьмин, С.Г. Кузьменков, С.М. Полукеев, М.В. Новиков, В.В. Коркунов // Недропользование XXI век. - 2014. - № 3. - С. 56-63.

16. Определение экономических условий эффективности освоения запасов баженовской свиты / А.В. Шпильман, Н.Н. Захарченко, 0.0. Душенко, С.А. Филатов // Нефтяное хозяйство. 2015. - № 9. - C. 14-17.

17. Оценка перспектив нефтеносности отложений баженовской свиты на территории деятельности ОАО «Томскнефть» ВНК / С.В. Парначев, Д.В. Воробьев, И.В. Гончаров, А.Г. Скрипкин, С.В. Захаров // Нефтяное хозяйство. - 2016. - № 4. - С. 22-26.

18. Районирование мегавпадин юго-востока Западной Сибири по плотности ресурсов сланцевой нефти тогурской и баженовской материнских свит / В.И. Исаев, Г.А. Лобова, А.К. Мазуров, В.И. Старостенко, А.Н. Фомин // Геология нефти и газа. 2018. - № 1. - C. 15-39.

19. Лобова Г.А. Нефтегазоносность нижнеюрских и доюрских отложений центральной части и юго-востока Западной Сибири по данным геотермии: автореф. дис. ... д-ра геол.-минерал. наук. - Томск, 2015. - 44 c.

20. Kurchikov A.R., Borodkin V.N. Stratigraphy and paleogeography of Berriasian-Lower Aptian deposits of Western Siberia in connection with the wedge-like structure of crosssection // Russian Geology and Geophysics. - 2011. - V. 52. - № 8. P. 859-870.

21. Kontorovich V.A. Petroleum potential of reservoirs at the Paleozoic-Mesozoic boundary in West Siberia: seismogeological criteria (example of the Chuzik-Chizhapka regional oil-gas accumulation) // Russian Geology and Geophysics. - 2007. - V. 48. № 5. - P. 422-428.

22. Paleozoic-sourced petroleum systems of the West Siberian Basin. What is the evidence? / E. Ablya, D. Nadezhkin, E. Bordyg, T. Korneva, E. Kodlaeva, R. Mukhutdinov, M.A. Sugden, P.F. Van Bergen // Organic Geochemistry. - 2008. - № 39. P. $1176-1184$.

23. Koveshnikov A.E., Nesterova A.C., Dolgaya T.F. Fracture system influence on the reservoirs rock formation of Ordovician-Devonian carbonates in West Siberia tectonic depression // IOP Conference Series: Earth and Environmental Science. - 2016. - № 43. pp. 1-7. URL: http://iopscience.iop.org/article/10.1088/ $1755-1315 / 43 / 1 / 012008 / p d f$ (дата обращения 10.08.2018). 
24. Лобова Г.А., Лунева Т.Е., Кириллина М. С. Районирование перспектив нефтегазоносности доюрских резервуаров Нюрольской мегавпадины (по данным палеотемпературного моделирования и бурения) // Известия Томского политехнического университета. Инжиниринг георесурсов. - 2018. - Т. 329. - № 3. C. $123-133$.
25. Белозёров В.Б., Гарсия Бальса А.С. Перспективы поиска залежей нефти в отложениях Девона юго-восточной части Западно-Сибирской плиты // Известия Томского политехнического университета. Инжиниринг георесурсов. - 2018. - Т. 329. № 6. - C. 128-139.

Поступила 17.09.2018 г.

\section{Информация об авторах}

Кузьменков C.Г., доктор геолого-минералогических наук, профессор кафедры нефтегазового дела Института природопользования Югорского государственного университета.

Исаев В.И., доктор геолого-минералогических наук, профессор отделения геологии Инженерной школы природных ресурсов Национального исследовательского Томского политехнического университета; ведущий научный сотрудник кафедры нефтегазового дела Института природопользования Югорского государственного университета.

Булатов В.И., доктор географических наук, профессор кафедры нефтегазового дела Института природопользования Югорского государственного университета.

Аюпов Р.ШІ, кандидат технических наук, доцент кафедры нефтегазового дела Института природопользования Югорского государственного университета.

Игенбаева H.O., кандидат географических наук, доцент кафедры нефтегазового дела Института природопользования Югорского государственного университета.

Кузьлин Ю.А., кандидат геолого-минералогических наук, заведующий отделением геологического моделирования и подсчёта запасов углеводородов АУ «Научно-аналитический центр рационального недропользования им. В.И. Шпильмана».

Стулов П.А., первый заместитель директора АУ «Научно-аналитический центр рационального недропользования им. В.И. Шпильмана». 
UDC 553.98.042:622.32(571.12)

\title{
DEVELOPMENT OF YUGRA OIL AND GAS COMPLEX, HARD-TO-EXTRACT RESERVES
}

\section{Stanislav G. Kuzmenkov'}

ksg.1948@ya.ru

\author{
Valeriy I. Isaev ${ }^{2,1}$ \\ isaevvi@tpu.ru
}

Valery I. Bulatov',

bulatov.40@mail.ru

\section{Roman Sh. Ayupov',}

ayupovrsh@gmail.com

Natalya O. Eginbaeva',

nataligeo@yandex.ru

Yuri A. Kuzmin ${ }^{3}$,

kuzmin@crru.ru

Peter A. Stulov',

StulovPA@nacrn.hmao.ru

1 Yugra State University,

16, Chekhov street, Khanty-Mansiysk, 628012, Russia.

2 National Research Tomsk Polytechnic University,

30, Lenin Avenue, Tomsk, 634050, Russia.

${ }^{3}$ Research and Analytical Center for Rational Use of the Subsoil named after V.I. Shpilman, 75, Malygin street, Tyumen, 625026, Russia.

${ }^{4}$ Research and Analytical Center for Rational Use of the Subsoil named after V.I. Shpilman, 2, Studencheskaya street, Khanty-Mansiysk, 628007, Russia.

The relevance. Crucial task for the Khanty-Mansiysk Autonomous District (Yugra), the main hydrocarbon crude and petroleum production base of Russia, is prevention of decline and stabilization of petroleum recovery. This can be arranged by vigorous integration of hard-to-extract reserves in exploration.

The aim of the research is to determine sources, directions and priorities of increasing oil resource base and stabilization of oil production in Yugra, with focus on potential of hard-to-extract reserves.

object: resources from allocated and unallocated subsoil reserve funds, volumetric oil production of main petroleum companies and major fields, hydrocarbon plays.

Research methods: look back analysis and prognosis of oil reserves and oil production dynamics, oil geological and mining classification of hard-to-extract reserves.

Results. The authors have analyzed the data of the Department for Subsoil Use of the Khanty-Mansiysk Autonomous District (Yugra) and «Research and analytical center for rational use of the subsoil named after V.I. Shpilman». 98,9\% volumetric oil production in Yugra belongs to nine integrated oil companies, $51,7 \%$ of volumetric oil production accounts for 14 large-scale deposits. The situation of petroleum recovery in Yugra since 1964 is analyzed, with detail starting from 2008, when predicted decline in oil production for the period up to 2030 was prepared. The prediction was fully confirmed in 2018. The paper introduces the logical causes of decline in petroleum recovery with the forecast of production decline to 220 million tons by 2020. One of the reasons is the objects discovered and introduced in exploration over the last years, which are generally the hard-to-extract reserves. Based on mining and geological factors seven groups of deposits with hard-to-extract reserves were identified, and real oil reservoir differentiation of Yugra was given. It is shown that one of the real source, providing stabilization of oil extraction, is vigorous integration of hard-to-extract reserves in exploration of Achimov and Tyumen plays, where the volumetric oil production have increased in 5-10 times since 2000. Growth of hard-to-extract reserves production of pre-Jurassic play is possible. Its cumulative production is 32 million tons. Resources of Bazhenov-Abalak play, which will be involved in exploration until 2030, can compensate for falling oil production in Yugra.

Key words:

Decline in petroleum recovery, hard-to-extract reserves, Bazhenov-Abalak play, Achimov, Tyumen and pre-Jurassic plays, Yugra.

The authors thank Sergey A. Filatov, the director of the Department of subsoil use and natural resources, KhMAD-Yugra, and Aleksandr V. Shpilman, the director of «Research and Analytical Center for Rational Use of the Subsoil named after V.I. Shpilman» for possibility in using geological information. 


\section{REFERENCES}

1. Kontorovich A.E. I.M. Gubkin's paradigm of the development of the USSR oil industry in the 20th century. Russian Geology and Geophysics, 2017, vol. 58, no. 3-4, pp. 283-293.

2. Kontorovich A.E., Eder L.V., Filimonova I.V. Paradigm oil and gas complex of Russia at the present stage. IOP Conference Series: Earth and Environmental Science, 2017, no. 88, pp. 1-5. Available at: http://iopscience.iop.org/article/10.1088/ 1755-1315/84/1/012010/pdf (accessed 10 August 2018).

3. Kontorovich A.E., Eder L.V., Filimonova I.V. Key Problems in the Development of the Power of Siberia Project. Regional Research of Russia, 2018, vol. 8, no. 1, pp. 92-100.

4. Shpil'man A.V. Tendentsii razvitya neftegazovoy otrasli i vozmozhnosti stabilizatsii dobychi nefti v Yugre [Tendencies of development of oil and gas branch and possibility of stabilization of oil production in Yugra]. Puti realizatsii neftegazovogo i rudnogo potentsiala Khanty-Mansiyskogo avtonomnogo okruga-Yugry. T. 1 [Ways of realization of oil and gas and ore capacity of KhantyMansi Autonomous Okrug. Vol. 1]. Khanty-Mansiysk, Izdatnaukaservice Publ., 2012. pp. 29-36.

5. Lisovskiy N.N., Khalimov E.M. On classification of hard-to-recover reserves. TsKR Rosnedra bulletin, 2005, vol. 1, pp. 33-35. In Rus.

6. Klassifikatsiya zapasov nefti i goryuchikh gazov [Classification of reserves of oil and combustible gases]. Moscow, Ministry of Natural Resources of the Russian Federation Publ., 2013. 9 p.

7. Polukeev S.M., Shpil'man A.V., Kuz'min Yu.A., Kuz'menkov S.G., Korkunov V.V., Novikov M.V. Stabilization of oil production in Yugra due to hardly removable stocks - the myth or reality. Nedropolzovanie XXI vek, 2013, vol. 5, pp. 12-19. In Rus.

8. Kuz'menkov S.G. In Yugra a polygon "Bazhenov» is being developed. Nedropolzovanie XXI vek, 2014, vol. 5, pp. 9-11. In Rus.

9. Lobova G.A., Isaev V.I., Fomin A.N., Stotsky V.V. Searches Shale Oil in Western Siberia. International Multidisciplinary Scientific Geoconference (SGEM 2016): Science and Technologies in Geology, Exploration and Mining: Conference Proceedings. Albena, 28 June - 7 July 2016. Sofia, STEF92 Technology Ltd, 2016. Vol. 1-3, pp. 941-948.

10. Zubkov M.Yu. Regional forecast of the oil bearing capacity of the Bazhenov suite. Russian Geology and Geophysics, 2017, vol. 58, no. 3-4, pp. 504-510. In Rus.

11. Belozerov V.B., Krasnoshchekova L.A., Merkulov V.P. Shale strata development problems and origin of the Bazhenov Formation fractures in the southeast of the West Siberian Plate. Russian Geology and Geophysics, 2018, vol. 59, no. 1, pp. 88-95.

12. Skvortsov M.B., Nemova V.D., Panchenko I.V., Kirsanov A.M. Criteria of oil content of sediments of the Bazhenov suite. Geology of oil and gas, 2018, no. 1, pp. 109-114. In Rus.

13. Ryzhkova S.V., Burshtein L.M., Ershov S.V., Kazanenkov V.A., Kontorovich A.E., Kontorovich V.A., Nekhaev A.Y., Nikitenko B.L., Fomin M.A., Shurygin B.N.,Beizel A.L., Borisov E.V., Zolotova O.V., Kalinina L.M., Ponomareva E.V. The Bazhenov Horizon of West Siberia: structure, correlation, and thickness. Russian Geology and Geophysics, 2018, vol. 59, no. 7, pp. 846-863.

14. Prishchepa 0.M., Averyanova 0.Yu. To the discussion of the conceptual base of non-traditional sources of oil and gas - shale stra- ta. Oil and gas geology. Theory and practice, 2013, vol. 1, no. 3. In Rus. Available at: http://www.ngtp.ru/rub/9/27_2013.pdf (accessed 10 August 2018).

15. Kuz'min Yu.A., Kuz'menkov S.G., Polukeev S.M., Novikov M.V., Korkunov V.V. Hardly removable reserves of oil of bazhenovsky deposits of KhMAO-Yugra. Nedropolzovanie XXI vek, 2014, vol. 3, pp. 56-63. In Rus,

16. Shpil'man A.V., Zaharchenko N.N., Dushenko 0.0., Filatov S.A. Determination of economic conditions for the efficiency of the development of reserves of the Bazhenov suite. Oil Industry, 2015, no. 9, pp. 14-17. In Rus.

17. Parnachev S.V., Vorob'ev D.V., Goncharov I.V., Skripkin A.G., Zaharov S.V. Estimation of oil-bearing prospects for the sediments of the Bazhenov suite on the territory of OAO Tomskneft VNK. Oil Industry, 2016, no. 4, pp. 22-26. In Rus.

18. Isaev V.I., Lobova G.A., Mazurov A.K., Starostenko V.I., Fomin A.N. Division into districts of megahollows of the southeast of Western Siberia on density of resources of slate oil of togur and bazhenov maternal suites. Geology of oil and gas, 2018, no. 1, pp. 15-39. In Rus.

19. Lobova G.A. Neftegazonosnost nizhneyurskikh i doyurskikh otlozheniy tsentralnoy chasti i yugo-vostoka Zapadnoy Sibiri po dannym geotermii. Avtoreferat Dis. Dokt. nauk [Oil and gas content of the Lower Jurassic and pre-Jurassic sediments of the central part and southeast of Western Siberia according to geothermy data. Dr. Diss. Abstract]. Tomsk, 2015. 44 p.

20. Kurchikov A.R., Borodkin V.N. Stratigraphy and paleogeography of Berriasian-Lower Aptian deposits of Western Siberia in connection with the wedge-like structure of crosssection. Russian Geology and Geophysics, 2011, vol. 52, no. 8, pp. 859-870.

21. Kontorovich V.A. Petroleum potential of reservoirs at the Paleozoic-Mesozoic boundary in West Siberia: seismogeological criteria (example of the Chuzik-Chizhapka regional oil-gas accumulation). Russian Geology and Geophysics, 2007, vol. 48, no. 5, pp. $422-428$.

22. Ablya E., Nadezhkin D., Bordyg E., Korneva T., Kodlaeva E., Mukhutdinov R., Sugden M.A., Van Bergen P.F. Paleozoic-sourced petroleum systems of the West Siberian Basin. What is the evidence? Organic Geochemistry, 2008, no. 39, pp. 1176-1184.

23. Koveshnikov A.E., Nesterova A.C., Dolgaya T.F. Fracture system influence on the reservoirs rock formation of Ordovician-Devonian carbonates in West Siberia tectonic depression. IOP Conference Series: Earth and Environmental Science, 2016, no. 43, pp. 1-7. Available at: http://iopscience.iop.org/article/10.1088/ 1755-1315/43/1/012008/pdf (accessed 10 August 2018).

24. Lobova G.A., Luneva T.E., Kirillina M. S. Zoning of oil and gas potential prospects of pre-Jurassic reservoirs of the Nyurol megabasin (according to paleotemperature modeling and drilling data). Bulletin of the Tomsk Polytechnic University. Geo Assets Engineering, 2018, vol. 329, no. 3, pp. 123-133. In Rus.

25. Belozerov V.B., Garsiya Balsa A.S. Prospects for the search for oil deposits in the Devon sediments of the southeastern part of the West Siberian plate. Bulletin of the Tomsk Polytechnic University. Geo Assets Engineering, 2018, vol. 329, no. 6, pp. 128-129. In Rus. 


\section{Information about the authors}

Stanislav G. Kuzmenkov, Dr. Sc., professor, Yugra State University.

Valeriy I. Isaev, Dr. Sc., professor, National Research Tomsk Polytechnic University; senior researcher, Yugra State University.

Valery I. Bulatov, Dr. Sc., professor, Yugra State University.

Roman Sh. Ayupov, Cand. Sc., associate professor, Yugra State University.

Natalya O. Iginbaeva, Cand. Sc., associate professor, Yugra State University.

Yuri A. Kuzmin, Cand. Sc., head of the department of geological modeling and reserve calculation, Research and Analytical Center for Rational Use of the Subsoil named after V.I. Shpilman.

Peter A. Stulov, senior vice-president, Research and Analytical Center for Rational Use of the Subsoil named after V.I. Shpilman. 